\title{
The Study of Synonymous. Word "Mistake"
}

\author{
Albertus Suwardi \\ Technology University of Yogyakarta
}

\begin{abstract}
This article discusses the synonymous word 'mistake'. The discussion will also cover the meaning of 'word' itself. Words can be considered as form whether spoken or written, or alternatively as composite expression, which combine and meaning. Synonymous are different phonological words which have the same or very similar meanings. The synonyms of mistake are error, fault, blunder, slip, slipup, gaffe and inaccuracy. The data is taken from a computer program. The procedure of data collection is by clicking the rightmouse on the word mistake. The synonyms of mistake are error, fault, blunder, slip, slipup, gaffe and inaccuracy. The data is taken from a computer program. The procedure of data collection is by clicking the right-mouse on the word. Mistake is the most general and used in most situations.
\end{abstract}

Key words: Synonymous, mistake, lexeme.

\section{A. Introduction}

Words may be considered as form, whether spoken or written, or alternatively, as composite expressions, which combine form and meaning (Lyons: 1995). Words used in languages refer to a term 'lexeme' as the technical term of dictionary - words. "Lexemes are items listed in the lexicon, or 'ideal dictionary' of . a language" Cruse (1986). In the relation of the words and the study of meaning in language, lexical semantics is an appropriate discussion. According to Cruse (2000) the lexical semantics studies the meanings of words and the focus here is on 'content' words like mistake, fault, and error rather than 'grammatical' words like 'the, of, and than'. What Cruse (2000) state is similar to what in http://www.socius. fi/Comm Comp.html "Lexical semantics is concerned with the analysis of word meanings and relations between them for example synonymy". The word mistake on the example above is synonymous with fault and error. The interesting of them are why they are synonymous and what makes them different. 


\section{B. Discussion}

\section{B.1 Definition of Mistake}

According to Saed, (1997, p.65), synonyms are different phonological words which have the same or very similar meanings. It is very unlikely that two words will be synonymous on every occasion- if they were, it would not be necessary to have both words in the language. So, 'when we use the term synonymy we are actually talking about partial synonymy' (Gairns and Redman, 1986, p.23) http://www.celt.stir.ac.uk/call99/Kostas/page4.htmI October 3, 2005. Take the word mistake, as the example, that has synonym with fault, error, blunder, slipup, gaffe, and inaccuracy. The definition of those words can be seen latter quoted from Oxford Advanced Learner's dictionary by Hornby. However before discussing them, I give the definition of mistake more complete from different source.

According to http://www.cogsci.princeton.edu/cgi-bin/webwn2.0? stage $=1$ \&word =mistakes. The noun "mistake" has 3 senses

1. mistake, error, fault -- a wrong action attributable to bad judgment or ignorance or inattention.

Eg. He made a bad mistake.

She was quick to point out my errors.

I could understand his English in spite of his grammatical faults.

2. mistake, misunderstanding, misapprehension -- an understanding of something that is not correct.

Eg. He wasn't going to admit his mistake.

Make no mistake about his intentions.

. There must be some misunderstanding--I don't have a sister. .

3. error, mistake --part of a statement that is not correct.

Eg. The book was full of errors.

Based on the definitions above that the word 'mistake' can be defined into three in each of which there is something different. The first definition is related to judgment of wrong action, the second is concerned on understanding, and the third is focused on the correctness of statement. According to Hornby (1995) the word 'mistake' as noun is defined as 
1. an action or opinion that is foolish or wrong; error judgment

Eg. This isn't my bill there must be some mistake.

2. Aword, figure, or sum that is not correct

Eg. The waiter made a mistake in adding up the bill.

From the definitions of mistake mentioned by Hornby and http://www.cogsci. princeton. edu/cgi-bin/webwn2.0, mistake refers to something involving action, opinion, statement, figure or sum that has not been done correctly or properly.

\section{B.2 The Synonymy of Mistake}

The synonyms of mistake are error, fault, blunder, slip, slipup, gaffe and inaccuracy. The data is taken from a computer program. The procedure of data collection is by clicking the right-mouse on the word mistake. After appearing some items, click the word synonym. The result of it is appearing the synonymous words of mistake.

To find their differences needs to know their definitions quoted from Oxford Advanced Learner's dictionary, Hornby (1995). There are also some examples taken from different sources in the part of texts to get clarity. They are as follows.

Error: 1. a thing done wrongly; mistake

Eg. An error of judgment

2. the state of being wrong in beliefand behavior

Eg. The accident was the result of pilot error.

Author: $\quad$ Clarendon Edward Hyde lst Earl of

Title: $\quad$ A SURVEY OF MR HOBBES HIS LEVIATHAN

Source: $\quad$ http://www.accd.edu/sac/english/bailey/clarendo.ht

Subject: $\quad$ ENGLISH \& ANGLO-SAXON LITERATURES (82)

... enter into the Lists with Mr Hobbes upon the Signification of words, or Propriety of expressions, in which he exercises an absolute Dictatorship; and indeed not to enlarge upon any particular that to me seems erroneous, except it be an error of that kind and consequence, as carries with it, or in it, somewhat that is hurtful to the Peace and Policy of the Kingdom, or prejudicial to the sincerity of Religion; I should have passed over the first, second, and 


\section{Author: Bastiat Frederic \\ Title: $\quad$ THE LAW \\ Source: $\quad$ http://www.acton.org/resources/libtrad/bastiat.htm \\ Subject: ECONOMICS (33)}

..: dissipation, idleness, sloth, envy, hatred, or jealousy? What you have leamed about the republic of Sparta should enlighten you on this question. No other state has ever had laws more in accord with the order of nature; of equality." The error of the Socialist Writers Actually, it is not strange that during the seventeenth and eighteenth centuries the human race was regarded as inert matter, ready to receive everything -- form, face, energy, movement, life -- from a great prince or a great

Blunder: a stupid of or careless mistake

Eg. An administrative blunder

\section{Author: Wheatley Henry}

Title:

\section{LITERARY BLUNDERS}

Source: $\quad$ http://promo.net/pg/ authors/wheatley henry benjam

Subject: $\quad$ OTHER LITERATURES (899)

... 118>war_. Is a not andiron (handirons) a parallel word of the same genus? In the General Index we find "Andwar, an old English word. So much for the long life of a very small blunder. A very similar blunder to this of "andwar" occurs in_Select Remains of the learned John Ray with his Life by the late William Derham_, which was published in 1760 with a dedication to the Earl of Macclesfield, President of the Royal Society, signed

\section{Author: $\quad$ Gaskell Elizabeth}

Title:

SYLVIA'S LOVERS

Source: http://lang.nagoya-u.ac.jp/ matsuoka/EG-Sylvia-1.h

Subject: ENGLISH FICTION (823)

... to. 'I'm right enough; just fairly wearied out: lost my way," and he fainted. There was a recruiting sergeant of marines sitting in the house-place, drinking. $\mathrm{He}$, too, like Philip, had lost his way; but was turning his blunder to account by telling all manner of wonderful stories to two or three rustics who had come in ready to drink on any pretence; especially if they could get good liquor without paying for it. The sergeant rose as Philip 
Fault : 1. an aspect of something that is wrong or not perfect

Eg. I like him in spite of all his fault.

2. the responsibility for mistake or offense

Eg. The fault really lies with the leadership of the movement.

Author: Mill John Stuart

Title: $\quad$ REPRESENTATIVE GOVERNMENT

Source: http://www.constitution.org/jsm/rep_gov.htm

Subject: ENGLISH ESSAYS (824)

... forth the armed apostle of a new religion; or unless the military chiefs ally themselves with his influence, and turn it into a prop for their own government. A. people are no less unfitted for representative government by the contrary fault to that last specified; by extreme passiveness, and ready submission to tyranny. If a people thus prostrated by character and circumstances could obtain representative institutions, they would inevitably choose their tyrants as their representatives, and the yoke would be made

\section{Author: James Henry}

Title: THE GOLDEN BOWL

Source: http://www.newpaltz.edu/ hathaway/

Subject: FICTION (813)

... her, however, to encourage him; she was now conscious of having never in her life stood so still or sat, inwardly, as it. were, so tight; she felt like the horse of the adage, brought-and brought by her own fault--to the water, but strong, for the occasion, in the one fact that she couldn't be forced to drink. Invited, in other words, to understand, she held her breath for fear of showing she did, and this for the "

Slipup: a careless mistake; (Slip: a minor error caused by being careless or not paying attention.)

Eg. He recited the whole poem without makings single slip.

Eg. We cannot afford another slip-up like this one. 
Author: Lewis Sinclair

Title: $\quad$ MANN STREET

Source: http://www.textlibrary.com/download/main-st.txt

Subject: FICTION (813)

... Clark's but----" "Well, y' ought get 't in. do to put off getting a stove all summer, and then have it come cold on you in the fall." Carol smiled upon them ingratiatingly. "Do you dears mind if I slipup to bed? rather tired--cleaned the upstairs today." She retreated. She was certain that they were discussing her, and foully forgiving her. She lay awake till she heard the distant creak of a bed which indicated that Kennicott

\section{Author: Irving Henry B.}

Title: $\quad$ A BOOK OF REMARKABLE CRIMINALS

Source: http://promo.net/pg/ authors/irving_henry brodribb

Subject: $\quad$ MISCELLANEOUS WRITINGS (818)

... proposed to search the house. Some customers in the shop told them that if they had any business with Mrs. Peace, they ought to go round to the side door. The polite susceptibility of these customers gave Peace time to slipup to a back room, get out on to an adjoining roof, and hide behind a chimney stack, where he remained until the detectives had finished an exhaustive search. So importunate were the officers in Hull that once again during

Gaffe: a social mistake; en embarrassing act or remark.

Eg. He didn't realize what a gaffe he'd made.

Author: Cooperc Alan

Title: ALLABOUT HOMONYMS GLOSSARY

Source: $\quad$ http://www.cooper.com/alan/homonym_list.html

Subject: DICTIONARIES \& ENCYCLOPEDIAS (503)

... strong point forth a direction fourth following the third foul grossly offensive to the senses fowl domestic hen or rooster frees releasing freeze very.cold frieze a wall decoration friar a monk fryer small chicken $G$ gaff a barbed spear gaffe a mistake gage a pledge or security deposit gauge instrument for measuring gait a 
manner of walking or nunning gate fence door gaited describing a walking horse gated having a gate galley ship"s kitchen gally to frighten or terrify gallop

Author: Montaigne Michel De

Title: $\quad$ MONTAIGNE'S ESSAYS: BOOK I

Source: http://www.uoregon.edu/ rbear/montaigne/index.htm\#

Subject: FRENCH ESSAYS (844)

... wipe their tailes (this vaine superstition of words must be left unto women) with a sponge, and that's the reason why Spongia in Latine is counted an obscene word: which sponge was ever tied to the end of a gaffe, as witnesseth the story of him that was carried to be devoured of the wild beasts before the people, who desiring leave to go toe a privie before his death, and having no other meanes to kill himselfe, thrust downe

Inaccuracy: something that is not correct or accurate.

Eg. The writer is guilty of bias and inaccuracy.

Author: $\quad$ Project Gutenberg

Title: $\quad$ THE PROJECT GUTENBERG ENCYCLOPEDIA

Source: $\quad$ http://promo.net/pg/ titles/i- t27.html\#theproject

Subject: $\quad$ DICTIONARIES \& ENCYCLOPEDIAS (403)

... not that it cannot take place. The best examples of partial or complete acclimatization are to be found where European races have permanently settled in the tropics, and have maintained themselves for several generations. There are,

- however, two sources of inaccuracy to be guarded against, and these are made the most of by the writers above referred to, and are supposed altogether to invalidate results which are otherwise opposed to their views. In the first place, we have the possibility o

Author: Bridgman Percy

Title: $\quad$ THE LOGIC OF MODERN PHYSICS

Source: $\quad$ http://webug.physics.uiuc.edu/courses/phys150/fall

Subject: $\quad$ MODERN PHYSICS (539) 
... of the operations by which length is to be determined becomes indefinite, so that the distances of the most remote stellar objects as estimated by different observers or by different methods may be very divergent. A particular consequence of the inaccuracy of the astronomical measures of great distances is that the question of whether large scale space is Euclidean or not is merely academic. We thus see that in the extension from terrestrial to great stellar distances the concept of length

\section{Analysis}

From the definition and the examples from different sources, error is something that is done wrongly. It can be wrong in decision, belief, behavior, or calculation. In the first example by Hyde, error is related to the wrong decision and the second one by Frederic is wrong in the belief. When compared to the word blunder, the cause of the mistake is different. Blunder is the mistake caused by one's stupidness or carelessness and it is not formal context. This can be seen in the examples of Henry and Elizabeth. Then, the word slipup, it is also focused on the careless; however the mistake is not like in blunder. The mistake in slipup is minor not too bad. It can be caused by not giving attention or sleepy when doing something.

In the word fault, the mistake is related to perfectness. Sometimes it is related to the one's responsibility. The example of Henry shows that responsibility for offense is more dominant. It is similar to the example of Stuart that the focus of the mistake is in the responsibility. Other synonymy of the word mistake is Gaffe. It is a nore specific mistake. It focuses on the social mistake. And the last is inaccuracy. It is the mistake that one does something not accurate.

\section{Conclusion}

Based on the definitions of words which are synonymous, they must have something similar and different that differentiates each other. Hornby (1995) says that they all refer to something that has not been done comectly or properly. Mistake is the most general and used in most situations. The synonyms of mistake are error, fault, blunder, slip, slipup, gaffe and inaccuracy. The data is taken from a computer program. The procedure of data collection is by clicking the right-mouse on the word mistake. 


\begin{tabular}{|l|l|l|l|l|l|l|l|}
\hline \multicolumn{7}{|c|}{ THE SYNONYMOUS WORDS } \\
\hline Mistake & error & Fault & blunder & Slip-up & Oversight & Gaffe & Inaccuracy \\
\hline Error & Mistake & Fault & Blunder & booboo & Slip & slip-up & Inaccuracy \\
\hline Fault & Mistake & Error & Blunder & Slipup & Slip & Burden & Liability \\
\hline Blunder & Mistake & Error & slip-up & mix-up & Gaffe & Howler & Bungle \\
\hline Oversight & Mistake & error & Slip & Lapse & $\begin{array}{l}\text { Misunder- } \\
\text { standing }\end{array}$ & Omission & $\begin{array}{l}\text { Supervis- } \\
\text { ion }\end{array}$ \\
\hline slip-up & Mistake & Error & blunder & Slip & Blemish & Defect & $\begin{array}{l}\text { Imperfect- } \\
\text { ion }\end{array}$ \\
\hline Gaffe & Mistake & error & blunder & $\begin{array}{l}\text { False- } \\
\text { move }\end{array}$ & & - & \\
\hline $\begin{array}{l}\text { Inaccura- } \\
\text { cy }\end{array}$ & $\begin{array}{l}\text { Mistaken } \\
\text { ness }\end{array}$ & $\begin{array}{l}\text { Errone } \\
\text { ousness }\end{array}$ & $\begin{array}{l}\text { Incorrect- } \\
\text { ness }\end{array}$ & $\begin{array}{l}\text { Inexact- } \\
\text { Ness }\end{array}$ & $\begin{array}{l}\text { Imprecis- } \\
\text { ion }\end{array}$ & $\begin{array}{l}\text { Wrong- } \\
\text { ness }\end{array}$ & \\
\hline
\end{tabular}

\section{Bibliography}

Cruse, D. Alan. 2000. Meaning in Language An Introduction to Semantics and Pragmatics. New York: Oxford University Press.

Cruse, D. Alan. 1986. Lexical Semantics. New York: Cambridge University Press.

Hornby. 1995. Oxford Advanced Learner's Dictionary. New York: Oxford University Press.

Lyons John. 1995. Linguistic Semantics An Introduction. New York: Cambridge University Press.

http://www.ez-homework.com/term-papers/345492/meaning-of-mistakes-vserrors-in-language.html. .

http://www.cogsci.princeton.edu/cgi-bin/webwn2.0

http://www.celt.stir.ac.uk/call99/Kostas/page4.html

http://www.celt.stir.ac.uk/call99/Kostas/page4.html

http://www.socius.fi/Comm_Comp.html 